\title{
"Costuma fornecer a diversas pessoas drogas abortivas": o ofício das parteiras, disputas profissionais e sociabilidades femininas (Porto Alegre, RS, Primeira República)
}

\author{
"Usually provides several people with abortion drugs": Midwifery, \\ professional disputes and female sociability (Porto Alegre, RS, \\ First Republic)
}

\section{Paulo Staudt Moreira* Nikelen Acosta Witter**}

Resumo: O artigo versa sobre o ofício das parteiras, sua importância social, as disputas por clientela e as sociabilidades femininas que giravam em torno deste exercício profissional. A parteira era uma presença limite entre a vida e a morte, entre um bom parto e um desfecho indesejado. Era ela que trazia a criança ao mundo, cortava o cordão umbilical, cuidava da mulher que acabara de parir, limpava o recém-nascido, providenciava (às vezes, no próprio pátio da casa dos pais) o enterro do natimorto, batizava os nascidos in periculo mortis, amadrinhava os sobreviventes. A análise dessa trabalhadora da saúde usa documentos judiciários como observatórios sociais e através deles maneja o cruzamento com outras fontes, procurando as experiências sociais das agentes ali presentes, tanto no exercício do ofício como recebendo atendimentos diversos. Parte das mulheres que aparecem neste artigo, se consultando ou usando efetivamente os serviços das parteiras, são trabalhadoras do serviço doméstico, assim, também versaremos sobre questões desse universo laboral. O lócus de nossa pesquisa é a cidade de Porto Alegre, capital do estado do Rio Grande do Sul, na parte mais meridional do Brasil.

Palavras-chave: parteira; sociabilidades femininas; saúde.

* Doutor em História - UFRGS, professor titular da Universidade do Vale do Rio dos Sinos - Unisinos, bolsista de Produtividade em Pesquisa do CNPq - Nível 2. E-mail: moreirast@terra.com.br. ORCID: https://orcid.org/00000003-1286-2874.*

** Doutora em História Social pela Universidade Federal Fluminense. Professora da Universidade Federal de Santa Maria - UFSM. Coordenadora do Grupo de Estudos e Extensão Universidade das Mulheres - GEEUM@. E-mail: nikelen@gmail.com. ORCID: https://orcid.org/0000-0002-1394-0806. 
Abstract: The article deals with the midwifery profession, its social importance, the disputes for clientele and the female sociability that revolved around this professional exercise. The midwife was a limit presence between life and death, between a good birth and an unwanted outcome. It was she who brought the child into the world, cut the umbilical cord, took care of the woman who had just given birth, cleaned the newborn, provided (sometimes, in the parents' own courtyard) the stillbirth burial, baptized the born in periculo mortis, he hurried the survivors. The analysis of this health worker uses judicial documents as social observatories, and through them handles the crossing with other sources, looking for the social experiences of the agents present there, both in the exercise of their profession, as well as receiving diverse assistance. Part of the women who appear in this article, consulting or effectively using the services of midwives, are domestic service workers, thus, we will also discuss issues of this work universe.

Keywords: midwife; female sociability; health.

Entre o criado e o patrão:

- Saiba o patrão que o serviço da parteira já foi dispensado.

- Está bom. É menino?

- Não, senhor; cousa melhor.

- Menina?

- Não, senhor; cousa melhor.

- Então que diabo é?

- Saiba o patrão que a patroa morreu...

(HDBNRJ - Jornal O Republicano, ano VI,

São Sebastião do Caí, n. 297, 25 dez. 1910).

- arcástica e desagradável aos historiadores, a anedota acima - publicada junto com - várias outras no dia de natal de 1910 - dialoga com o público leitor da época que, talvez, fosse rir do desfecho da narrativa. Mas a ironia sobre o falecimento da patroa serviria também como uma catarse daquela comunidade a respeito de um momento bastante delicado e atemorizador daquele cotidiano social - o parto. A morte da mulher e de seu rebento, no momento do parto, era uma constante naquela sociedade e essa fragilidade tornava ainda mais importante uma figura central naquele cenário - a parteira. A parteira ali estava como uma presença limite entre a vida e a morte, entre um bom parto e um desfecho indesejado. Era ela que trazia a criança ao mundo, cortava o cordão umbilical, cuidava da mulher que acabara de parir, limpava o recém-nascido, providenciava (às vezes, no próprio pátio da casa dos pais) o enterro do natimorto, batizava os nascidos in periculo mortis, amadrinhava os sobreviventes. É sobre o ofício dessa mulher trabalhadora que o artigo versa. 
O controle praticado pelo "conhecimento médico" sobre as entranhas das mulheres foi adquirido através da medicalização do parto, isto é, com a entrada dos médicos na vida das mulheres e a consequente substituição das parteiras. Estes trouxeram para o aparato jurídicopolicial conhecimentos que permitiam maior controle sobre a sexualidade das mulheres. O que, por outro lado, fez com que a "vontade de saber", apresentada na forma de perguntas, acabasse se constituindo, durante $o$ inquérito, como uma forma de investigação e apropriação das mulheres sobre seu corpo e práticas. ${ }^{1}$

\section{O caso contra Joana}

EM 25 dE AGosto DE 1890, o promotor público José de Almeida Martins Costa Júnior enviou ofício ao juiz de Direito do $2^{\circ}$ Distrito Criminal de Porto Alegre, acusando a parteira Joana Mehnert de fornecer pílulas abortivas para uma mulher que a procurou pedindo ajuda. Tratava-se da criada Matilde Peltz, empregada na casa de Jacob Krauss, que em setembro de 1889, estando grávida de três meses "e indo entender-se sobre o seu estado com a denunciada, que aqui exerce a profissão de parteira, esta cientemente forneceu-lhe pílulas de efeito abortivo, tendo ido Matilde efetivamente dar à luz na própria casa da denunciada". Esse fato foi relatado à mulher de Jacob Krauss pela própria Matilde, mas o promotor público chama atenção de que esse procedimento da parteira Joana não foi esporádico, sendo regularmente por ela praticado:

[...] não é, entretanto, o único neste gênero praticado pela denunciada; da leitura dos depoimentos colhidos no inquérito junto, verifica-se ter tido a denunciada igual procedimento criminoso para com outras pessoas, constituindo-se assim useira e vezeira em semelhante crime. ${ }^{2}$

A historiografia tem sido "useira e vezeira" no uso operacional dos documentos judiciários como fontes históricas. Produzidos como instrumento de averiguação, punição e controle social, os dossiês jurídicos depositados em nossos arquivos históricos conservam vestígios de experiências sociais relacionadas ao trabalho, ao gênero, à sexualidade, às hierarquias e pertencimentos étnico-raciais etc. Ou seja, esses documentos criminais, produzidos originalmente como artefatos repressivos, nos trazem um amplo repertório de práticas e de representações sociais, através dos ofícios dos profissionais do direito e da saúde (nos autos de corpo de delito, por exemplo) e dos depoimentos dos réus/rés, testemunhas e vítimas (ofendidos). Cabe aqui perfeitamente a expressão de Carlo Ginzburg, de que os processos criminais são uma "mina de dados involuntários (isto é, não procurados pelos juízes)", nos trazendo, também opiniões comunitárias sobre práticas diversas. ${ }^{3}$

1 PEDRO, Joana Maria. A experiência com contraceptivos no Brasil: uma questão de geração. Revista Brasileira de História, São Paulo, v. 23, n. 45, p. 239-260, 2003. p. 119.

2 APERS - Tribunal do Júri, Comarca Especial de Porto Alegre, 1889. Autora: a justiça; ré: Joana Mehnert. Crime: dar drogas de efeito abortivo.

3 GINZBURG, Carlo. Provas e possibilidades à margem de "Il ritorno de Martin Guerre", de Natalie Davis. In: A micro-história e outros ensaios. Lisboa: DIFEL; Rio de Janeiro: Bertrand Brasil, 1991. p. 183. 
O promotor público Costa Júnior, convicto da culpa da parteira Joana, pedia sua condenação nas penas da segunda parte do artigo 300 do Código Penal, promulgado pelo Decreto $n^{\circ} 847$, de 11 de outubro de 1890, que tipificava o crime de aborto.

Por se tratar de uma área circunscrita ainda basicamente às mulheres - a maternidade, o parto, o aborto -, majoritariamente foram chamadas outras mulheres para atestarem sobre o ocorrido e mesmo sobre acontecimentos pretéritos, mas que envolveram a parteira Joana Mehnert. Ao todo foram 10 testemunhas, sendo apenas um homem chamado a depor. $\mathrm{O}$ qual, certamente o foi, por ser o dono da casa onde estava empregada a criada Matilde. Ou seja, os homens que protagonizavam aquele julgamento - juízes, promotores, autoridades policiais, jurados, médicos - tateavam indecisos por um campo por eles pouco conhecido, daí terem que recorrer a mulheres para Ihes relatar as ocorrências. Fica claro aí que as mulheres possuíam um universo próprio, ainda pouco permeável aos homens. Nesse espaço, que era o corpo e a saúde feminina, o conhecimento acumulado pelas parteiras não podia ainda ser rivalizado por nenhuma parte da ciência masculina.

As parteiras tinham aí uma posição de destaque. Por um lado, seu conhecimento empírico do corpo feminino as tornava também curadoras das doenças das mulheres, por outro havia a confiança e a proximidade estabelecida no trato dos partos e das enfermidades, o que Ihes mantinha uma clientela fiel e o respeito de toda a comunidade. ${ }^{4}$

Joana Mehnert morava na época no $4^{\circ}$ distrito de Porto Alegre, por isso quem primeiro se encarregou das investigações foi o subdelegado daquela região, João Hilgert. Como veremos depois, esse subdelegado era amigo ou parente de outra parteira, Helena Mierisch Wagner, com quem Joana Mehnert tinha desentendimentos que não sabemos se eram "apenas" de disputa de clientela ou de outra natureza. Usando de seu cargo de subdelegado, João Hilgert promoveu as primeiras investigações, dizendo que chegou ao seu conhecimento que a parteira Joana costumava "fornecer a diversas pessoas drogas abortivas".

O alemão Jacob Frederico Krauss, o único homem a depor, contou que Matilde esteve empregada como criada em sua casa por dois ou três meses antes do aborto até maio de 1889, e que hoje está no município de Estrela, no lugar denominado Teotônia. Krauss tinha 30 anos de idade, era casado e ocupava-se como comerciante. No depoimento na polícia, Jacob declarou categoricamente que sua criada "abortou uma criança devido a remédios que forneceu a parteira Joana Mehnert, tanto assim que ele testemunha foi queixar-se à autoridade presente". Tudo isso, Jacob sabia por ouvir de sua mulher, Rosa. No depoimento na justiça, Jacob parecia mais inseguro e contou que Matilde ficara na casa de Joana de dois a quatro dias, ficando devendo à parteira 41 mil réis, dos quais pagou 10 mil por intermédio de seu patrão. O aborto teria ocorrido no mês de setembro de 1888 , na casa da parteira Joana, mas ele não sabia se foram as pílulas que causaram tal problema.

4 WITTER, Nikelen Acosta. Dizem que foi feitiço. As práticas da cura no sul do Brasil (1845 a 1880). Porto Alegre: EDIPUCRS, 2001. p. 139. 
A criada Matilde Peltz veio do município de Santa Cruz - naquela época ex-colônia de imigrantes alemães - para a capital do estado, Porto Alegre, centro urbano que comportava consistente colônia alemã desde o século XIX. ${ }^{5} \mathrm{Da}$ capital ela foi para Teotônia, outro núcleo de imigração europeia, majoritariamente alemã. Talvez ela tenha vindo de Santa Cruz grávida, pensando em resolver a questão longe de sua família e comunidade. Mas, de qualquer maneira, suas opções de deslocamento consideraram variáveis étnicas, pois se empregou com uma família de origem germânica na capital da província e depois se deslocou para outra cidade com perfil demográfico que a beneficiava em termos culturais, linguísticos etc. Muitas das testemunhas desse processo necessitaram de tradutor para entender o que era perguntado e poderem se expressar corretamente para as autoridades, o que demonstra a existência de núcleos de germanidade em um local urbano, com exíguas ou limitadas relações com a população nativa.

A esposa de Jacob, Rosa Krauss, também depôs. Ela tinha 23 anos, era natural da Alemanha, assinou o depoimento. Quanto a sua ocupação ou ofício, disse ser do serviço doméstico, mas como tinha em casa duas criadas, certamente ela queria dizer que não trabalhava fora de seu domicílio, mas gerenciava a casa do casal, mesmo que ajudasse em pequenas tarefas. ${ }^{6} \mathrm{Na}$ polícia ela contou que apenas sabia que a parteira Joana forneceu, nos dias 12 ou 13 de setembro, a uma criada que esteve alugada em sua casa umas "pílulas para abortos", e que isso Ihe disse a própria criada Matilde Peltz. Mas não sabe se Matilde pediu o tratamento ou se a parteira ofereceu por si. Disse ainda que Matilde foi para a casa da ré quando começou a sentir as dores do parto. Joana Mehnert, então, fez uma pergunta procurando responsabilizar o subdelegado pela denúncia:

P. se o subdelegado João Hilgert não foi à casa dela testemunha intimá-la para comparecer no inquérito que ia abrir contra a denunciada, ensinando-lhe nesta ocasião as respostas que deveria dar, bem assim, se quando ela testemunha depôs perante aquela autoridade, a mesma autoridade não Ihe fazia as perguntas em alemão, para depois mandá-las escrever em português. R. que o subdelegado Hilgert falou com seu marido para este ir depor no inquérito, mas como seu marido respondesse que só sabia o que havia lhe referido ela testemunha, então o subdelegado disse-lhe que quem deveria comparecer era ela testemunha; sendo certo que por ocasião do inquérito o subdelegado fazia-Ihe as perguntas em alemão, mandando depois escrever as mesmas em português.

Além da culpabilização do subdelegado pela montagem da denúncia, o trecho acima mostra que a polícia convocou primeiro para depor o dono da casa, iniciativa típica de uma sociedade

5 GANS, Magda Roswita. Presença teuta em Porto Alegre no século XIX: 1850-1889. Editora da UFRGS. Porto Alegre, 2004.

6 GRAHAM, Sandra Lauderdale. Proteção e obediência. Criadas e seus patrões no Rio de Janeiro, 1860-1910. São Paulo: Companhia das Letras, 1992; TELLES, Lorena Féres da Silva. Libertas entre sobrados. Mulheres negras e trabalho doméstico em São Paulo (1880-1920). São Paulo: Alameda, 2013; SOUZA, Flavia Fernandes de. Criados, escravos e empregados. O serviço doméstico e seus trabalhadores na construção da modernidade brasileira (cidade do Rio de Janeiro, 1850-1920). Tese (Doutorado em História) - Instituto de Ciências Humanas e Filosofia, Departamento de História, Universidade Federal Fluminense, Rio de Janeiro, 2017. 
patriarcal. Mas, como era da alçada das mulheres os assuntos envolvendo a gestão dos corpos femininos e entre elas é que circulavam as informações, os auxílios e as sugestões, a dona da casa teve de ser chamada a depor.

Outras testemunhas foram convocadas para incriminar Joana, mas a estratégia de acusação não deu nada certo. Uma delas foi a também trabalhadora do serviço doméstico e natural da Alemanha, Emma Nitz. Esta tinha 33 anos de idade, era analfabeta e disse que nada sabia e nem ouviu dizer do caso de Matilde. A testemunha também negou ter ido à autoridade denunciar a parteira Joana. Afirmou que apenas "disse em conversa íntima" que Barbara Franzen perdera uma criança e que esta declarou que "tinha tomado remédio para matar a criança, e isto fez de seu moto próprio".

Como foi citada no depoimento de Emma, Bárbara Franzen compareceu frente às autoridades. Declarou ser criada do serviço doméstico, ter 20 anos, ser natural do estado e solteira. Assinou o depoimento. Bárbara igualmente alegou ignorar tudo a respeito do caso de Matilde e esclareceu que morou um tempo na casa de Joana, onde teve uma criança, com nove meses, que morreu seis horas depois. Ela não sabia do que morreu o recém-nascido, mas o dr. Fayet, que foi examinar a criança, disse que ela morreu de convulsões.

A também trabalhadora do serviço doméstico Sofia Fechtner, nascida na Alemanha, era analfabeta, tinha 35 anos e era casada. Ela contou que teve um aborto em 28 de dezembro de 1888 "e que the parece ter abortado devido a um tombo que levou um mês antes". Nenhuma parteira assistiu ao aborto e ela só conferenciou com a parteira Joana Mehnert, porque "já há um mês que andava sofrendo dores" e ela apenas lhe disse "que não trabalhasse, não Ihe receitando nada para tomar". Depois de ter abortado, chamou a parteira "para examiná-la, visto que ela testemunha andava muito doente", e esta, indo a sua casa, aconselhou-a que chamasse um médico. Veio então a sua casa o dr. Joaquim Brenfeld, "depois de conferenciar com a parteira Mehnert, receitou e tratou a testemunha por espaço de 15 dias".

$\mathrm{Na}$ casa de Jacob e Rosa Krauss também trabalhava outra criada, Maria Luiza Müller, a qual também foi chamada a depor. A testemunha Maria Fleck depôs que Luiza sofrera um aborto e que a criança nascera morta, mas não citou a parteira Joana em seu testemunho. Porém, Josefina Hildebrando - que na polícia disse trabalhar no serviço doméstico e na justiça disse ser costureira - contou outra história. Josefina disse que Maria Fleck the dissera que Maria Luiza abortara uma criança "devido a remédios (drogas) que Ihe forneceu a parteira Joana". Josefina assume que ela testemunha foi à subdelegacia denunciar esse fato e que Maria Fleck the disse que a criança nasceu viva. Tal história foi contada pela testemunha para a esposa do delegado Hilgert, mas que ela "não fez propositalmente e em intenção de denunciar a acusada". A criança de Maria Luiza teria nascido na casa que esta dividia com Maria Fleck, no beco dos Cacetes.

A ré Joana Mehnert-que, como era de praxe, estava presente ao depoimento - interpelou a testemunha Josefina, perguntando se o subdelegado não a instou para que não faltasse 
ao depoimento, pagando a sua passagem de bonde e "também (n)o dia que compareceu à polícia?". Josefina respondeu que nada recebeu, mas que o subdelegado Hilgert the disse que ela era obrigada a depor, pois já havia falado a respeito do caso em sua casa. A parteira Joana contestou o depoimento de Josefina, dizendo que a testemunha era íntima de Hilgert.

Sendo citada, foi intimada a depor a outra criada que trabalhava para o casal Krauss. Maria Luiza Müller tinha 27 anos, era casada, natural do estado e assinou o depoimento. $\mathrm{Na}$ polícia, a respeito do caso de Matilde, disse nada saber, nem ouvir dizer, mas reconheceu que em dezembro, ela testemunha tivera um aborto, "em uma espécie de bola, o qual tinha três meses e que foi enterrado no quintal de sua casa, tendo-lhe assistido como parteira Joana Mehnert".

$\mathrm{Na}$ justiça, Maria Luiza foi bem mais falante (talvez se sentindo pressionada pelas autoridades judiciárias) e contou que Matilde Peltz chegara de Santa Cruz do Sul, de onde já veio grávida, e que logo disse que estava adoentada, com dores de cabeça e "de faltas de evacuação". Maria Luiza então aconselhou-a a procurar um médico ou uma parteira, e ela consultou-se com Joana. A parteira Ihe receitou umas pílulas do Doutor Brandão Schweitzer, "as quais foram tomadas pela metade somente por Matilde, que seis meses mais tarde teve um aborto". Luiza não sabe se o aborto foi causado pelas pílulas e contou que Matilde teve a criança na casa de Joana para onde foi "meia hora antes de dar à luz a criança".

Respondendo a uma interpelação da própria ré Joana, Luiza respondeu que se dava com Matilde "como companheiras da mesma profissão, não sendo amigas íntimas" e que ela não se mostrava desejosa de abortar e que nunca atribuíra o aborto às tais pílulas. Matilde devia a Joana pelo tratamento $20 \$$ réis, mas ela não pagou integralmente a quantia "devido a sua pobreza". Ainda respondendo à ré Joana, Luiza disse que não sabia de inimizades da acusada com as testemunhas (e parteiras) Helena e Clara, mas elas falavam muito mal da ré.

Logo depois foi chamada para depor a parteira Clara Geidel, também natural da Alemanha, trabalhadora do serviço doméstico, com 30 anos de idade, casada e que assinou o depoimento. Na polícia, Clara foi contundente, dizendo que ouvira falar que a parteira Joana "fornecia drogas abortivas a diversas pessoas", mas que não se lembrava quem lhe disse isso. Na justiça, Clara depôs que nada sabia do caso de Matilde, pois ela na ocasião estava ausente do país, na Alemanha. Mas contou que a senhora de Ernesto Paulo, conhecida por Faéca, "disse que, querendo abortar uma criança, visto sofrer muito por ocasião de seus partos", entendeu-se com Joana "e por meio de um ferro que esta lhe forneceu, conseguiu o que desejava, isto é, a expulsão do feto". A senhora que abortara pediu que ela testemunha nada contasse, porque estava bem de saúde e tratada pelo dr. Barcelos Filho. Clara contou que era vizinha e amiga da senhora que abortara (cujo nome não é citado), "mas a amizade ficou algum tanto abalada quando ela contou o segredo em juízo e depois no dr. Fayet, "por ocasião de um parto que ela testemunha assistiu".

Aproveitando a deixa, a ré Joana perguntou se a testemunha "tem por profissão partejar ou por costume?", e ela respondeu que "não tem por profissão partejar, mas algumas vezes, 
em falta de parteira, ela tem exercido as funções desta". Foi então perguntado se Clara já passara atestado como parteira provisionada e ela retorquiu que não, mas que existia um "papel destes em que ela figura como parteira provisionada, mas tal qualificação não foi escrita por ela e que ocorreu assim":

Em dezembro do ano passado, dona Helena Meirich Wagner, não podendo ir pessoalmente assistir a uma parturiente, mulher de Israel Amorim, professora de fora da cidade, pediu-lhe que fosse em seu lugar assistir a dita parturiente, dizendo-Ihe que mais tarde iria ver a mesma. Poucas horas depois dela testemunha ter chegado à casa da parturiente, esta deu à luz a uma criança morta, já em estado de putrefação. Compreendendo-se a necessidade de enterrar sem demora o recém-nascido, o marido da parturiente escreveu um papel em que relatava à autoridade o fato da morte da criança e pediu a ela que assinasse esse papel, ao que ela anuiu, por ter sido este fato da morte presenciado por muitas pessoas e não lhe parecer por isso haver compromisso no que fazia, cumprindo dizer que apenas lançou o seu nome, sem qualificativo algum. Feito este escrito, foi ele apresentado à autoridade policial, que posteriormente mandou intimá-la para exibir seus títulos de habilitação e justificar-se por aquela assinatura. Intimada ela testemunha foi à casa do dr. Coutinho, a este referiu o modo que tinha assinado o tal papel, e mais tarde leu no jornal alemão Kozeritz o despacho de um requerimento que havia feito, no qual se terminara a questão. ${ }^{7}$

Ajudando-nos a compreender a origem do desafeto que parecia unir aquelas mulheres, a ré Joana Mehnert pergunta à testemunha Clara Geidel se ela sabia, naquela ocasião descrita acima, que ela acusada é que a denunciara à Inspetoria da Higiene Pública e à Chefatura de Polícia? "Respondeu que até aquele fato eram amigas, tendo ela testemunha protegido muito a acusada em sua profissão, mas essa amizade acabou-se desde que ela testemunha foi denunciada pela mesma acusada".

O palco policial e judiciário estava montado, esperando a presença de uma personagem nodal naquele enredo. Essa personagem já foi citada no depoimento de Maria Luiza, quando ela diz que as parteiras Helena e Clara falavam sempre muito mal da ré Joana, parteira como elas. Helena Mierisch Wagner era casada com Germano Wagner, tinha 38 anos, natural da Alemanha, parteira provisionada e alfabetizada. ${ }^{9}$

Na polícia, Helena Wagner contou que não tinha certeza de que Joana fornecesse drogas abortivas as suas parturientes, pois ela nunca assistiu a isso. Mas, em dezembro ("cuja data

7 APERS - Tribunal do Júri, Comarca Especial de Porto Alegre, 1889. Autora: a justiça; ré: Joana Mehnert. Crime: dar drogas de efeito abortivo.

8 A historiadora argentina Andrea Reguera, ao analisar as redes sociais e afetivas do indivíduo por ela biografado, chama atenção dos "círculos de inimigos", que ela recomenda serem parcimoniosamente observados. REGUERA, Andrea. Patrón de estancias. Ramón Santamarina: una biografía de fortuna y poder en la pampa. Buenos Aires: Eudeba, 2006.

9 O Curso de Partos foi fundado em 1897 pelos doutores em medicina Protásio Alves, Deoclécio Pereira e Sebastião Leão, visando qualificar parteiras para atuar no estado. Aliás, em $1^{\circ}$ de agosto de 1899 , um edital da Diretoria de Higiene, publicado no jornal $A$ Federação, tornava pública uma lista dos que se achavam inscritos para exercer profissões diversas da área da saúde, como médicos, farmacêuticos, dentistas diplomados e parteiras. Entre estas últimas, as parteiras, estavam inscritas como diplomadas no estrangeiro e habilitadas na Faculdade de Medicina do Rio de Janeiro, justamente as desafetas Henriqueta Helena Mierisch Wagner e Joanna Mehnert. E como não diplomadas: Joana Guerra, Manoela Rodrigues Agostini, Maria Christina Rodrigues, Maria Pennacchi (HDBNRJ - Jornal A Federação, 1 ago. 1899). 
não se recorda"), apareceu em sua casa um homem (de "meia-idade") e pediu-lhe "um remédio abortivo", ao que ela negou e o homem retrucou que Joana fornecia, mas que ele não recorria a ela "por ser muito indiscreta". Helena contou também que sabia que Sofia Fletcher teve um aborto e foi assistida por Joana. Disse também que Barbara Franzen falou-lhe, em casa de Frederico Linch, que devia tê-la chamado "quando esteve para ter uma criança e que ela testemunha se admiraria se soubesse o que Joana Menhert fazia, e que seu filho não teria morrido se chamasse ela testemunha para assisti-la". Barbara, além de dizer que deveria ter chamado Helena para partejá-la, disse que, quando estava na casa de Joana, "esta fez abortar uma mulher em sua própria casa e a testemunha não recorda se Barbara Franzen disse que essa mulher se chamava Becker ou se era uma criada que serviu em casa de Becker".

$\mathrm{Na}$ justiça, a parteira Helena inseriu outros detalhes na sua narrativa. Ela contou que o dr. Birnfeld lhe disse que havia sido chamado em 6 de janeiro à casa de uma Volkmer, na rua da Misericórdia, a fim de ver ali uma doente. Lá, encontrou Sofia Fechtner enferma em função de um aborto e a parteira Joana estava ali presente. $\mathrm{O}$ doutor pediu para ver o feto, mas Joana lhe disse que esperasse a dona da casa sair do quarto e daí mostrou-lhe o feto em um vidro. Helena contou que na época não conhecia Sofia, mas depois ela veio a sua casa, recomendada pelo dr. Birnfeld, "pedir para lhe ensinar meios de não conceber mais, dizendo que tinha tido um aborto acompanhado de muitos sofrimentos, e que o dr. Birnfeld, médico que chamara, Ihe tinha aconselhado que tomasse cuidado a fim de não conceber mais, pois tal fato lhe era prejudicial", ao que Helena enfaticamente depôs que a isso não se prestou.

Na sua qualificação como ré, Joana Mehnert se apresenta como filha de Cristiano Jürgensen, com 41 anos de idade, casada, natural da cidade de Kappel, na Alemanha, e alfabetizada. Ela morava no Caminho Novo (atual Voluntários da Pátria) há um ano mais ou menos e conhecia todas as testemunhas há muito tempo, atribuindo a acusação a perseguições de João Hilgert, Clara Geidel e Helena Mierisch Wagner. Anexado ao processo existe um texto assinado por Joana, de 2 de outubro de 1890, no qual ela diz que tudo que está passando era fruto de vingança.

Em 16 de junho daquele ano, o marido de Joana apresentou uma queixa por crime de calúnia contra o delegado Hilgert, por injúrias feitas a sua mulher. João Hilgert foi pronunciado por sentença do juiz de Direito do $2^{\circ}$ distrito, sendo o teor da calúnia o mesmo da presente denúncia. Foi só em 28 de junho que o subdelegado iniciou as diligências preparatórias do inquérito policial - "é visto, pois, que o procedimento da autoridade policial foi filho de um sentimento de vingança, nem sequer julgou-se moralmente incompatível para presidir as diligências policiais e promover o presente sumário". ${ }^{10}$ Nada incriminava nos depoimentos a acusada, pois

10 Ramão de Jesus Bidart, escrivão da subdelegacia de polícia do $3^{\circ}$ distrito, confirma a ação de calúnia movida por Augusto Meinhert contra o subdelegado João Hilgert em 16 de junho. A audiência ocorreu em 2 de julho, sendo o subdelegado pronunciado por sentença, mas Augusto desistiu da ação em 24 de julho. 
percebe-se "a vacilação dos depoimentos, o espírito de ódio, intuitos de vingança, uma surda maquinação da maledicência com que se quis lançar a consternação no seio de uma família, amargurar um esposo, desesperar tristes crianças, cuja mãe se quer oprimir por [...] ódios insaciáveis, pobre mulher sem outras afeições que não as do seu lar, sem outro amparo que não o indefectível espírito de justiça do ilustre juiz julgador, guarda sereno da liberdade individual". Segundo Joana, os doutores citados, Barcelos Filho e João Birnfeld, estavam dispostos a depor "contra a veracidade do fato criminoso".

Mesmo após a leitura do documento apresentado por Joana, o promotor José de Almeida Martins Costa Júnior declara que a denúncia possuía base jurídica, independente dos motivos que deram origem ao inquérito policial. Pelos depoimentos, segundo o promotor, mostra-se "o hábito em que está a ré de cometer crimes desta natureza". O promotor também aponta que apenas uma semana decorreu entre a queixa do marido da ré e o início do inquérito policial. $E$ isso foi feito como "uma antecipação astuta, um meio de que lançou mão a denunciada para colocar a autoridade na situação embaraçosa de proceder contra uma pessoa que pelo mesmo fato lhe instaurara processo".

Pelo que consta nos autos, a parteira Joana Mehnert foi presa na cadeia civil apenas na véspera da sessão do júri, que ocorreu em 31 de dezembro de 1890. Os homens reunidos como juízes de fato decidiram, por unanimidade, que a acusada não forneceu, "com conhecimento de causa, pílulas de efeito abortivo para Matilde Peltz". O juiz José Camilo de Revoredo Ramos, então, absolveu a ré.

No entanto, os atritos entre as duas profissionais não se encerraram nas atas desse processo criminal. Em outubro de 1890, a parteira Joana Mehnert (e seu marido Augusto) encaminharam à justiça uma queixa-crime contra João Mierisch, Germano Wagner, João Hilgert e Helena Mierisch Wagner. Joana conta que "há muito tempo [é] vítima de perseguição", tendo já processado por calúnia João Hilgert. Além disso, Helena (combinada com seu marido Germano Wagner e João Hilgert), por suas intrigas, fez com que Joana respondesse processo por fornecer drogas abortivas, sendo que João dizia que a desfeitaria em breve, logo que reassumisse o cargo de subdelegado do $2^{\circ}$ distrito. ${ }^{11}$

A queixa feita relata que, em 23 de outubro de 1890, estava Joana em sua casa na rua Voluntários da Pátria, "quando ouviu tocarem a campainha do corredor" e "acudindo ao chamado foi agredida com surpresa pelo querelado João Mierisch, irmão de Helena Wagner e cunhado de Germano Wagner, que descarregou-Ihe diversas bengaladas, produzindo na ofendida os ferimentos constantes do auto de corpo de delito". O agressor:

11 APERS - Juízo substituto do $2^{\circ}$ Distrito Criminal de Porto Alegre, sumário, n. do processo: 1727; réu: João Hilgert e Helena Mierisch Wagner; autores: Augusto e Joanna Mehnert, 1890. 
[...] em ato contínuo deitou a correr, mas foi perseguido pelo clamor público e detido por homens do povo. Quando no meio desses chegaram Germano Wagner e João Hilgert, este último subdelegado em exercício havia cinco dias, ambos de emboscada que estavam à espera do ato.

Germano disse a seu cunhado que fugisse e Hilgert se recusou a efetuar a prisão, mas a "gente que ali estava" tornou a prender o agressor e Hilgert se viu obrigado a lhe dar voz de prisão. Porém, "no dia seguinte verificou-se que essa prisão fora um embuste, pois não dera entrada na cadeia o delinquente, nem contra o mesmo se lavrou auto de flagrante". A parte policial anexada ao processo confirma que a agressão ocorreu entre 8 e 9 horas da noite, e que a parteira Joana foi agredida na porta de sua casa. O processo não teve andamento, não se sabe se por os queixosos terem se sentido satisfeitos em levar os acusados à justiça, se por haver acordo entre as partes ou por falta de provas.

\section{A casa de Joana}

O MARIDO DE JoAnA, Carlos Augusto Mehnert, faleceu em 27 de maio de 1915, deixando a viúva, dois filhos: Max Mehnert (maior de idade, casado) ${ }^{12}$ e Ana Mehnert Toledo (viúva, deserdada pelos pais); e a neta Irma Mehnert Martins. ${ }^{13}$ Em 15 de julho do mesmo ano, preparando-se para o inventário dos bens do marido, Joana Mehnert consegue que o Juiz de Órfãos lhe nomeie tutora da menor púbere Irma Constância Mehnert Martins, filha de Ana Mehnert Toledo e do falecido João Alfredo Martins. ${ }^{14}$ Joana se apresenta no requerimento ao juiz como parteira, manejando seu ofício como uma insígnia de prestígio. ${ }^{15}$

Os bens arrolados se constituem de móveis diversos e dois terrenos, um na esquina das avenidas Brasil e São Paulo (de 120 palmos de frente e 175 de fundos) e outro também

12 No alistamento eleitoral de 1901, Max João Felipe Mehnert aparece com 25 anos de idade, filho de C. A. Mehnert, casado, trabalhador do comércio. HDBNRJ - Jornal A Federação, 5 jul. 1901, folha 4 - Alistamento eleitoral - $3^{a}$ seção - n. 1599.

13 APERS - Juízo Distrital da Vara de Órfãos de Porto Alegre, arrolamento n. 248. Inventariado: Carlos Augusto Mehnert; inventariante: Joana Mehnert, 1916.

14 Joana e Carlos redigiram um testamento conjunto, por isso, nessa pequena autobiografia que eles nos legaram, sabemos que eram ambos protestantes, "em cuja crença nascemos, nos criamos e pretendemos morrer". Os testadores eram casados e naturais da Alemanha. Ele se declara sapateiro e ela parteira. Carlos e Joana legam seus bens todos ao filho Max João Mehnert e à neta Irma Constança Mehnert Martins, deserdando a filha Ana Margarida, "por não mais a considerarmos como filha". Os motivos constam no testamento: (...) por ter a mesma, por várias vezes, desrespeitado o nosso lar, recebendo nele um seu amásio de nome Custódio Ribeiro da Silva, além de se ter prostituído. E, por excelência, por ter sido grandemente ingrata para conosco, injuriando-nos de pior forma concebível".

15 A parteira Joana manejava seu prestígio autonomamente, mantendo uma vida financeira própria à de seu marido. Em 1902 Joana Mehnert assinou uma letra, prometendo pagar em dois meses a quantia de duzentos mil réis, que Francisco Barbosa Fusquine naquele momento the emprestava. Fusquine deve ter ficado decepcionado, pois ela não conseguiu saldar a dívida e ele teve que entrar na justiça pedindo ressarcimento. O juiz dr. Alfredo Lisboa agendou uma audiência pública em 5 de setembro de 1903, mas a ré não compareceu, ficando acertado a sua revelia que ela saldaria a quantia em 10 dias. Talvez Joana e Francisco tenham se acertado particularmente, porque em 30/09 o mesmo juiz considerou encerrado o prazo, sem que o pagamento tivesse sido realizado e o processo se encerrou por aí. APERS - Juízo Distrital de Porto Alegre, Jurisdição Comercial, $\mathrm{n}^{\circ}$ do processo: 5858; suplicante: Francisco Barbosa Fusquine; suplicada: Joanna Mehnert, 1903. Porto Alegre/APERS. Juízo de Órfãos de Porto Alegre, Autos de petição de tutoria n. 69, menor púbere: Irma Constância Mehnert Martins; tutora: Joana Mehnert, 1915. 
na avenida São Paulo (82 palmos de frente e 250 de fundos). No primeiro terreno há quatro casas de material, com os números $82,82 \mathrm{~A}, 84$ e 86 e no segundo há um corredor com quatro casinhas. Nesses terrenos, o casal Mehnert deveria alugar pequenas peças ou casinhas para populares que chegavam à capital, talvez imigrantes sem grandes recursos ou empobrecidos, criadas estrangeiras que procuravam emprego na comunidade germânica aí instalada e que eram preferidas por seus patrícios às domésticas negras egressas da escravidão.

Acostumada a receber mulheres que necessitavam de cuidados em sua casa e tendo aperfeiçoado as habilidades necessárias à recepção e acomodação de pessoas, dona Joana Mehnert se tornou proprietária de uma casa de pensão. E alguns vestígios apontam que seus hóspedes eram de ambos os sexos. ${ }^{16}$

Contudo, o que interessa aqui, antes da casa de pensão, é a casa da parteira. Isto é, o fato de Joana receber suas clientes para partos, abortos (intencionais ou não) e outros cuidados em sua casa ou casas, pelo que se pode deduzir do inventário de seu marido. A primeira questão que trazemos à tona é o fato de que, mesmo com o acelerado processo do início do século $\mathrm{XX}$ em deslocar o centro de cuidados e atenção à saúde da casa dos particulares, esta ainda se constituía num ponto não desprezível da cartografia terapêutica das camadas populares. ${ }^{17}$ No caso das mulheres, mesmo com os avanços dos médicos-parteiros e da medicalização da atenção às moléstias femininas, ${ }^{18}$ é possível que esse processo tenha sido consideravelmente mais lento. Podem ter influído aí questões de pudor, mas também de confiança nas diferentes classes sociais. ${ }^{19}$

Isso nos leva à clientela de Joana Mehnert. Ao menos a clientela que aparece listada no processo analisado. Composta em grande parte de criadas do serviço doméstico, essas mulheres - pelo que se pode deduzir dos documentos - moram em quartinhos e ou na casa dos patrões. Isso raramente se constitui num ambiente adequado para o tipo de tratamento que necessitavam no momento de suas questões com partos e abortos. Assim, como aparece diversas vezes no processo, elas vão para a casa de Joana, onde são acolhidas e tratadas nos casos que a parteira considera ter condições de ação.

Esse espaço de cuidado dentro da casa da parteira configura-se também num espaço de trocas entre mulheres e de segredos de suas condições e mazelas. Na mesma época, as parteiras do interior relatavam ir morar na casa de suas clientes para auxiliá-las com casa, filhos

16 HDBNRJ - Jornal A Federação, 10 jun. 1905, folha 2 - "Registro Mortuário - Hoje, às 5 horas da manhã, foi encontrado morto, em adiantado estado de decomposição, Carlos Frederico (Schoel), de 44 anos de idade e filho do senhor $\mathrm{H}$. O. Schoel. O fato foi levado ao conhecimento do subintendente do $1^{\circ}$ distrito, major Francisco Louzada, pela proprietária do prédio $n^{\circ} 388$ da rua dos Andradas, onde é estabelecida com casa de pensão d. Joana Mehnert".

17 WITTER, Nikelen Acosta. Males e epidemias. Sofredores, governantes e curadores no sul do Brasil (Rio Grande do Sul, século XIX). Tese (Doutorado em História) - Universidade Federal Fluminense, Niterói, 2007.

18 WEBER, Beatriz Teixeira. As artes de curar. Medicina, religião, magia e positivismo na República Rio-Grandense - 1889/1928. Bauru/SMA: EDUSC/UFSM, 1999.

19 Sobre o processo de medicalização do parto, recomenda-se: SILVA, Caroline Santos. Com um fórceps na mão, há de se parir uma nação: ensino e prática da obstetrícia e ginecologia em Salvador (1876-1894). Dissertação (Mestrado em História) - Universidade Federal da Bahia, Salvador, 2011. 
e questões do resguardo considerado tão necessário à parturiente e ao recém-nascido. ${ }^{20}$ Sem casa própria - por vezes sem uma família própria -, as clientes de Joana Mehnert iam para a casa da parteira e, pelo que podemos depreender dos depoimentos, numa condição bem mais precária do que aquelas que podiam ter a parteira em sua própria casa. A precariedade vinha do fato de que elas relatam estarem envolvidas com trabalho ao sentirem as dores, depois, o fato de que sua convalescença parece ser abreviada, ou pela necessidade de trabalho ou de evadir-se da região (como parece ser o caso da criada Matilde).

Ainda no processo, podemos notar que Joana Mehnert não se reprime em chamar um médico, quando não se considera apta. $\mathrm{E}$, ao que parece, essa recíproca também existe da parte dos doutores, que indicam as parteiras inclusive para ensinar medidas contraceptivas, como foi visto anteriormente.

Outro fato a ser notado é que Joana Mehnert também tratava mulheres em suas casas ou de seus patrões, mas há condições individuais bem diferentes na vida de sua clientela, bem como diferentes recortes sociais das mesmas. Aí percebemos mulheres migrantes (não somente imigrantes de origem germânica, mas também que se deslocaram de outros núcleos coloniais), mulheres casadas (que pareciam lamentar seus abortos), mulheres solteiras (que afirmavam querer as crianças abortadas), mulheres que eram apoiadas pelos patrões em suas questões, outras nem tanto. Essas condições individuais podem apontar para inúmeras possibilidades de experiência, das quais podemos apenas suspeitar com base na documentação e em pesquisas realizadas em épocas análogas e em espaços passíveis de comparação.

Certamente não encontraremos nenhuma alegação a favor do aborto nesses processos. Afinal, já temos séculos da condenação deste por parte da religião e dos poderes governamentais. A repressão, no entanto, não parecia suficiente na época, como não parece ser agora. Percebe-se aí uma resistência das mulheres. Uma luta sub-reptícia para manter o controle sobre seus corpos e suas famílias e, certamente, sobre suas reputações, diante de um conjunto sociocultural que as condenava e excluía a partir de padrões cada vez mais fechados e restritos. ${ }^{21}$

Os estudos sobre contracepção apontam as técnicas abortivas como de uso regular entre as mulheres para controlar o número de filhos e não apenas como forma de se livrarem de "maus passos" ou "indiscrições". O conhecimento de técnicas contraceptivas, porém, foi

20 CARVALHO, Natália Silveira de. Mirem-se no exemplo daquelas mulheres: contracepção, dano à saúde e dispositivo da sexualidade. Revista Direitos Fundamentais e Alteridade, Salvador, v. 3, n. 1, p. 77-93, jan.jun. 2019; JARDIM, Rejane Barreto. Desvelando o implícito. Irmãs de caridade e parteiras na formação do saber médico em Porto Alegre, 1872-1940. Dissertação (Mestrado) - PPGH/Universidade Católica do Rio Grande do Sul, Porto Alegre, 1998; NECKEL, Roselane (et al.). Aborto e infanticídio nos códigos penais e nos processos judiciais: a pedagogia de condutas femininas. In: PEDRO, Joana Maria (org.). Práticas proibidas. Práticas costumeiras de aborto e infanticídio no século XX. Florianópolis: Cidade Futura, 2003; ROHDEN, Fabíola. A arte de enganar a natureza. Contracepção, aborto e infanticídio no início do século XX. Rio de Janeiro: Fiocruz, 2003; VÀZQUEZ, Georgiane Garabely Heil. Mais cruéis do que as próprias feras. Aborto e infanticídio nos Campos Gerais entre o século XIX e o século XX. Dissertação (Mestrado em História) Universidade Federal do Paraná, Curitiba, 2005.

21 MILLET, Kate. Política sexual. Lisboa: Publicações Dom Quixote, 1970; CARVALHO, op. cit. 
sendo abafado pelo modelo de sociedade patriarcal vigente. Este, além de impor o pudor e a reserva nas conversas femininas e troca de saberes, também regulava o acesso destas ao conhecimento, limitando-as e igualando o ideal de pureza e feminilidade à ignorância.

\section{"Gossip" e um outro olhar sobre a detração do universo feminino}

O PROCESSO CONTRA JOANA MEHNERT, entre outras coisas, chama atenção pela quantidade de mulheres citadas e chamadas a depor. São cerca de 11 mulheres citadas nominalmente e pelo menos mais quatro apenas mencionadas. Trata-se de uma rede expressiva - ou mais de uma - de mulheres que dão apoio e sustentam umas às outras por meio de diversos tipos de conexão: trabalho, amizade, partilha, acordos econômicos, conhecimento do corpo etc.

$O$ que podem nos dizer essas redes sobre o que era o mundo das mulheres nos alvores do século $X X$ ? Por que e de que forma esse mundo continuava a se reproduzir a revelia do controle masculino? Como esse mundo foi retratado na documentação do Estado brasileiro do início da República, o qual se orgulhava de suas insígnias patriarcais?

A historiadora Silvia Federici sugere que para que compreendamos a profundidade dessas ligações e redes é necessário que nos debrucemos sobre elementos da vida das mulheres que nos chegaram de forma deformada. Mais que isso, ela alerta para a mudança do sentido de alguns léxicos, outrora importantes à ligação entre as mulheres, e depois sendo temporalmente desfeitos e desacreditados em sua essência pela sociedade patriarcal.

Federici recupera então o sentido da palavra gossip, no inglês, e traduzida, normalmente, por fofoca, no português. Atualmente, ambas as palavras comportam o sentido de falas (quase invariavelmente femininas ou afeminadas) tolas, falsas, maledicentes e/ou frívolas. Originalmente, explica Federici, gossip era uma corruptela de God (Deus) sibb (aparentada). A palavra era usada por mulheres para designar outras mulheres que lhes eram muito próximas e, por volta dos séculos XIV a XVI, aparece em diversos tipos de escritos como uma forma de designar as melhores amigas. Para Federici, historiar esse termo permite perceber como $o$ ato de:

Imputar um sentido depreciativo a uma palavra que indicava amizade entre as mulheres ajudou a destruir a sociabilidade feminina que prevaleceu na Idade Média, quando a maioria das atividades executadas pelas mulheres era de natureza coletiva e, ao menos nas classes baixas, as mulheres formavam uma comunidade coesa que era a causa e a força sem par na era moderna. ${ }^{22}$

Para Federici, o modelo europeu exportado pelas grandes navegações, bem como pelos processos colonialista e imperialista, criminalizou de forma legislativa e cultural a amizade e a solidariedade feminina. Essas últimas constituíam um importante ponto de resistência das mulheres ao patriarcado e ao modelo econômico que este veio a adotar-o capitalismo. Federici

22 FEDERICI, Silvia. Mulheres e caça às bruxas. São Paulo: Boitempo, 2019. p. 75. 
aponta a caça às bruxas como o marco dessa ação de destruir a resistência das mulheres, separando-as por meio da desconfiança, bem como do desprezo social às atividades que estas faziam conjuntamente.

Porém, um processo como o que envolveu a parteira Joana Mehnert demonstra que parte desse mundo de profundas ligações entre as mulheres resistia, protegendo-as e aos seus segredos. Mas, Joana Mehnert e suas clientes já estão imbricadas em um mundo profundamente dominado pelo patriarcado masculino, aqui representado pela polícia, a justiça, os médicos, os maridos (que avalizam suas esposas profissionais-parteiras, mas as enfraquecem como sujeitas individuais - afinal, sem maridos, elas contam menos). Assim sendo, suas agências são vistas com enormes desconfianças, seus segredos são devassados, suas ações são apresentadas como condenáveis e perigosas para toda a comunidade.

$E$, como na caça às bruxas, semear a desconfiança entre mulheres que antes confiavam umas nas outras parece ser a tática mais eficiente de desbaratar qualquer célula de resistência feminina.

\section{Essa aventureira que para fazer nome foi casar-se na cadeia: a parteira Helena Mierisch Wagner}

VISANDO TORNAR MENOS ABSTRATA a personagem da parteira Helena Wagner - a antagonista de Joana Mehnert -, começaremos a descrevê-la através de uma publicação feita por ela própria no jornal $A$ Federação (2/1/1891), quando o processo contra a parteira Joana ainda se desdobrava. Na Seção Livre desse órgão republicano, Helena publicou um extenso texto de sua autoria, com o título Aventureira. Nele, ela atacava a Germano Hasslocher, advogado de Joana Mehnert, que com esse epíteto - de aventureira - a ofendera na tribuna da defesa, "convertida em tribunal de difamação". ${ }^{23}$ Além disso, Hasslocher teria ofendido o irmão de Helena de vagabundo e o seu marido de "Germano com sua calceta". Helena acionou a positividade de sua posição de estrangeira e criticou tal "ignóbil procedimento, tão contrário ao que acostumamos apreciar no caráter brasileiro, tão contrário ao decoro de um tribunal e à civilização desta capital".

Helena reclama das injúrias pronunciadas em pleno tribunal, sem qualquer punição ou censura dos órgãos competentes, principalmente daquelas que tinham a intenção de ferir a honra de seu marido. Segundo ela, as torpes explosões de ira do advogado Germano Hasslocher quiseram transformar o seu nome em crime. De seu lado, ela atribui as ofensas proferidas a "inveja profissional, que desde certo tempo me move perseguição implacável com o fim de fazer-me retirar por meio de desgostos, ora com multa, ora com atentado contra o meu irmão, ora com querelas e chicanas".

23 HDBNRJ - Jornal A Federação, 2 jan. 1891 
Helena também escreve que fora obrigada a depor contra Joana Mehnert:

[...] e referi tão somente o que não se podia silenciar. Não desejava a desgraça dessa mulher, que deve a mim, em grande parte, a sua habilitação de parteira, como poderei provar com as pessoas a quem nesse sentido recorri. No começo de sua carreira, cedi-lhe parte das minhas clientes, cortei depois as relações com ela devido ao seu modo grosseiro e gênio rancoroso, pelo qual vive em eterna luta com suas colegas não diplomadas, que a cada momento denuncia, como poderá atestar a honrada inspetoria da higiene. Porém, o melhor de tudo é que, no princípio do processo - que sem o açulamento e chicanas do dr. Hasslocher não teria havido - procurou-me o doutor pedindo-me que eu não depusesse contra a sua constituinte, porque ele queria tão somente escangalhar e meter na cadeia o subdelegado João Hilgert etc., que bem sabia quem era a Joana Mehnert e do que ela é capaz, porque foi o advogado da acusação no processo que no Rio foi instaurado a Joana Mehnert por crime de assassinato, que ela evitou a prisão pela fuga para cá. Lembrei-me então de ter lido no Diário de Notícias, do Rio, o assunto "O Crime da Parteira". A transcrição desses artigos nos jornais desta capital, ou a certidão dos respectivos autos, teria causado um mal imenso a Joana Mehnert; nada disso fizemos porque não desejamos a desgraça de ninguém, nem dos que se prestam como instrumentos contra nós. Jamais pensei que num tribunal de uma capital fosse possível ser injuriada uma testemunha por ter cumprido seu dever, que fosse permitido invectivar uma mulher, que, embora pobre, nunca deu lugar de se poder duvidar de sua honra e decência - que a claque encarregada de abafar com bravo, muito bem o brado de indignação dos homens decentes, insultasse e ameaçasse o marido que protestava contra os ultrajes feitos a sua mulher ausente - Essa inqualificável covardia sirva de eterna vergonha ao seu autor. Helena Mierisch Wagner, Porto Alegre, $1^{\circ}$ de janeiro de 1891.

Nos números do jornal Diário de Notícias disponíveis na Biblioteca Digital da Biblioteca Nacional do Rio de Janeiro, não encontramos referências a esse "Crime da Parteira". O nome de Joana, entretanto, aparece em um número de 1888. Joana Emma Mehnert diplomou-se pelo Instituto de Partos de Dresden e, em julho de 1888, habilitou-se (como parteira estrangeira) para a prática do ofício na Faculdade de Medicina do Rio de Janeiro, sendo avaliada em anatomia descritiva, higiene, fisiologia e farmacologia. ${ }^{24}$

Como se vê pelo texto, a disputa de Helena Wagner era também em grande parte com o advogado Germano Hasslocher. Muitos documentos atestam essa longa briga, que envolveu o marido de Helena, Germano Wagner, e questões político-partidárias. Esmiuçá-los aqui, porém, fugiria ao escopo e limites deste artigo.

Já que nosso enfoque é sobre o trabalho e o ofício de parteira, interessa aqui observar alguns elementos que aparecem num processo movido contra ela por Germano Hasslocher por motivo de injúria. ${ }^{25}$ Nele, Helena anexa um documento de seu próprio punho, no qual transcreve o registro do atendimento que fez a Paulina Hasslocher (esposa de Germano) ${ }^{26}$

24 HDBNRJ - Diário de Notícias, Rio de Janeiro, ano IV, n. 1.144, folha 2, 31 jul. 1888.

25 APERS - Juízo Distrital, Porto Alegre. Queixa, autor: dr. Germano Hasslocher; ré: Helena Mierisch Wagner, 1899.

26 AHCMPA - Habilitação matrimonial - Germano Hasslocher e Paulina Ferraz, ano: 1890, n. 140. Foram padrinhos Paulo Pereira dos Santos e sua mulher Joaquina Viana dos Santos. 
em três consultas, cobrando de cada uma cinco mil réis. Paulina tinha, segundo parece, uma inflamação na vagina (vaginitis aguda) e, durante as consultas, Helena realizou exames, uma cauterização e receitou remédios (iodo, glicerina, unguento de zinco etc.). Abaixo dessa transcrição, ela acrescentou de próprio punho:

Esta é cópia - tradução exata do meu livro de assentos do ano 1890; como fiz meus estudos em língua francesa, e no ano referido 1890 ainda mui imperfeitamente escrevia o português, redigi as notas do respectivo em francês.

Não junto aos autos o referido livro, por serem contidos nele várias notas e receitas sobre tratamento de senhoras conhecidas nesta cidade; porém, se a autoridade assim o exigir, está o livro inteiramente a sua disposição.

[Assinado] Helena Mierisch Wagner, parteira diplomada.

Ou seja, Helena Mierisch Wagner, e talvez este tenha sido um procedimento padrão das parteiras diplomadas, tinha em seu poder um livro de assentos, onde anotava as mulheres que tratava e os males que as afligiam. Infelizmente, a autoridade judiciária não exigiu que ela entregasse esse documento, que nos daria um panorama detalhado do trabalho de uma parteira, dos males que afligiam as mulheres do período, dos diagnósticos e tratamentos recomendados. Porém, o último parágrafo da declaração de Helena demonstra como o tratamento das senhoras era, em grande parte, monopólio das parteiras, que tinham através dele acesso à intimidade das mulheres do período. A sensibilidade, além das habilidades curativas e a discrição, eram características fundantes do ofício dessas mulheres, o qual as posicionava de forma nodal naquela sociedade, já que se imiscuíam na vida cotidiana das famílias em momentos muito delicados.

Os serviços prestados pelas parteiras eram precariamente pagos de forma pecuniária, ficando sempre a sensação de uma dádiva de difícil retribuição. Daí, talvez se justifique convidá-las tão frequentemente para amadrinharem os rebentos que ajudaram a nascer. Essa retribuição material e simbólica era, também, fruto do receio que elas causavam pelas informações que detinham. Talvez aqui, a análise de Nikelen Witter (2007) sobre curadores e os conceitos de dom e contradom pudessem ser aplicados. Novamente nos vemos limitados pelos objetivos do artigo e apontamos que esse poder seria uma interessante análise a ser feita, inclusive reunindo outros documentos que envolvem a atuação das parteiras em princípios do século XX e além.

\section{"Um infanticídio hediondamente revelador da perversão moral de uma desalmada mãe"}

Alguns anos depois, nova suspeita rondou a parteira Joana Mehnert e as páginas do jornal A Federação foram ocupadas por difamações escritas por jornalistas homens, escandalizados com as ações de mulheres que arriscavam as suas reputações, não cumprindo - por vontade 
ou necessidades - os papéis que Ihes atribuíam como mães. A folha republicana, em 25 de abril de 1894, assim começa relatando o caso:

\begin{abstract}
Vamos descrever uma ocorrência que, assim como pode ter sido oriunda do propósito de abafar um desvio do caminho da honra, pode também encerrar um crime revoltante, um infanticídio hediondamente revelador da perversão moral de uma desalmada mãe. Uma mulher, de nome Catharina Nicolay, ex-criada do hotel Trein, de propriedade do cidadão Jacob Trein e situado à rua Vigário José Ignacio $\mathrm{n}^{\circ} 19$, apresentou-se há dias à parteira $\mathrm{d}$. Joana Mehnert, residente à rua $\mathrm{Dr}$. Flores $\mathrm{n}^{\circ} 32$, pedindo-lhe que a recolhesse a sua casa, pois que se achava enferma. Interrogada sobre se havia tido algum parto, Catharina respondeu à citada profissional que não, que os seus incômodos eram outros. ${ }^{27}$
\end{abstract}

A primeira coisa que chama atenção é a retórica masculina presente na notícia que, ao mesmo tempo em que espalha como um miasma a suspeita de que houve um crime, já qualifica o respectivo potencial delito - o infanticídio - de hediondo e a sua provável praticante de uma mãe sem alma e dotada de uma perversão moral. Só assim, cometido por uma mulher metamorfoseada em monstro imoral, se aceitaria esse desrespeito ao divino papel da maternidade. Mas outra questão chama a atenção do pesquisador, o fato da criada Catarina ter ido procurar ajuda ao seu problema de saúde na casa daquela parteira. A qual, como já apontado, era um local onde se atendiam, cuidavam e curavam mulheres atingidas por moléstias diversas e não só relativas ao parto e à gestação.

Aliás, não é exteriorizado qualquer estranhamento dos jornalistas com relação a esse fato, das casas das parteiras serem espaços com esse papel no tratamento dos males femininos. Talvez isso nos ajude a pensar o porquê de um número menor de mulheres serem atendidas na Santa Casa de Misericórdia local. ${ }^{28} \mathrm{O}$ desconhecimento médico do organismo feminino, o pudor das próprias mulheres em se deixar examinar, a resistência dos homens das famílias (maridos, amásios, pais, irmãos, filhos) em ver a intimidade das suas mulheres perscrutadas, todos esses e outros mais fatores tornavam necessários outros espaços de cura. As mulheres adoentadas podiam ser cuidadas nas suas próprias casas, atendidas pelas próprias mulheres daqueles fogos (parentes ou familiares), assim como vizinhas. Como o caso acima se refere a uma criada, é provável que esta necessitasse de um abrigo temporário em caso de doença.

Contudo, o jornal dos republicanos continuou a explorar a desgraça alheia, defendendo a moral dominante e fornecendo - aos pesquisadores - vestígios de experiências femininas populares. Segundo os republicanos, enquanto Catarina se abrigava e era recolhida à casa daquela parteira:

27 HDBNRJ - Jornal A Federação, folha 2, 25 abr. 1894. Grifos nossos.

28 WEBER, Beatriz Teixeira. As artes de curar. Medicina, religião, magia e positivismo na República Rio-Grandense - 1889/1928. Bauru/SMA: EDUSC/UFSM, 1999; WITTER, Nikelen Acosta. Males e epidemias. Sofredores, governantes e curadores no sul do Brasil (Rio Grande do Sul, século XIX). Tese (Doutorado em História) - Universidade Federal Fluminense, Niterói, 2007; ALMALEH, Priscilla. Ser mulher. Cotidianos, representações e interseccionalidades da mulher popular (Porto Alegre 1889-1900). Dissertação (Mestrado em História) - Universidade do Vale do Rio dos Sinos, São Leopoldo, 2018; ROSSI, Daiane Silveira. Assistência à saúde e à pobreza no interior do sul do Brasil (1903-1913). Tese (Doutorado em História das Ciências e da Saúde) - Fundação Oswaldo Cruz, Rio de Janeiro, 2019. 
A esse tempo o dono do hotel, indo ao quarto que a sua ex-criada havia desocupado, notou aí um insuportável mau cheiro, cuja procedência passou a procurar. Nesse empenho, revistando um baú que se achava a um canto, Trein deparou-se com o cadáver de uma criança já putrefato, e deu-se pressa em comunicar o achado ao sub-intendente do $2^{\circ}$ distrito da capital, sr. Berto Cirio. Ligados os fatos, chegou-se à conclusão de que fora Catharina quem dera à luz essa criança. Perguntada sobre o caso, diz a rapariga que o filho morrera logo após o parto e que para ocultar essa prova de uma falta cometida, visto como é solteira, escondeu o cadáver no baú. A polícia, porém, é que, não se conformando com a explicação, fez recolher hoje à cadeia civil a ex-criada Catharina para ver se realmente ela teve em vista apenas evitar a divulgação de um erro prejudicial a sua honra ou se foi além, cometendo a crueldade de interromper com a morte os primeiros vagidos do próprio filho e desse modo pondo-se abaixo do último dos irracionais. ${ }^{29}$

A última frase encerra uma série de tentativas do jornalista redator da notícia em convencer os leitores não só da culpabilidade de Catarina, mas de que ela assim agindo se exilava da humanidade, recusando papéis naturais relativos ao seu gênero. A folha joga Catarina em um dilema: ou escondeu o cadáver de seu filho natimorto e fez isso justificada em escamotear um erro prejudicial a sua honra, já que era solteira, ou cometeu um homicídio de um recém-nascido, cometendo a crueldade de interromper com a morte os primeiros vagidos do próprio filho e desse modo pondo-se abaixo do último dos irracionais. Mas, como dissemos, a figura de Catarina vai sendo moldada para se adequar à demonização feminina proposta. Ela é descrita como uma rapariga, alcunha que remete a uma moça de vida sexual no mínimo suspeita. $\mathrm{E}$ por três vezes o seu ofício como criada no hotel é acompanhado com a expressão ex, o que a retrata como uma desocupada.

Percebe-se aqui, talvez, a intersecção do gênero com a classe, já que parece que se tenta desaboná-la, atingindo-a em sua honra ou reputação profissional; afinal, ela teria sido dispensada pelo patrão. Não trata a folha republicana, e não sabemos se seus leitores sentiram a falta (mas certamente muitas das leitoras) do aspecto de ter sido aquela criada vítima de abuso (estupro) por parte de alguém da casa de seus amos ou do próprio patrão. $\mathrm{Na}$ verdade, é estranho que ela abandonasse o serviço no hotel e não carregasse, junto com suas bagagens, a prova de seu delito ou, no mínimo, deslize. Como em outros casos parecidos, a culpa ou responsabilidade da própria gravidez e a morte (natural, acidental ou criminosa) do feto, recai sobre a mulher, sendo o homem que a fecundou invisibilizado. Nem a mera suspeita de abuso é levantada, ficando Catarina Nicolay sozinha perante o julgamento daqueles homens republicanos e da justiça.

Pelo anúncio abaixo, a atividade das parteiras podia ser complementar ou paralela a dos médicos, auxiliando-os no tratamento da saúde feminina, ainda pouco conhecida e garantindo que os pudores e receios da própria mulher adoentada e de sua família fossem atenuados:

Agradecimento e Missas. José Martins de Lima Sobrinho, seus filhos e seu genro Manoel Marques Martins agradecem do íntimo da alma aos ilustres

29 HDBNRJ - Jornal A Federação, folha 2, 25 abr. 1894. 
doutores Dioclecio e Schmidt e à parteira Joana Mehnert pelos esforços e desvelos que empregaram para salvar da cruel enfermidade a sua estremecida esposa, mãe e sogra d. Maria Antônia dos Santos Lima, falecida a 17 do corrente; assim também ao distinto dr. Dias Campos, pelos serviços que prestou no doloroso transo do saimento do féretro; igualmente ao seu amigo sr. Felipe Bento da Mota e sua exm. ${ }^{a}$ esposa e mais pessoas que os acompanharam em sua dor. Agradecem mais as palavras de conforto que as ilustradas redações dos jornais lhes dirigiram; a todas as corporações que se fizeram representar, especificando o distinto Club Ginástico Rio Grandense pela fineza que dele receberam e a todas as mais pessoas que lhes trouxeram as suas condolências, assistiram a encomendação e acompanharam o enterro. Convidam aos seus parentes e pessoas de suas amizades para assistirem as missas que pelo eterno descanso da alma da finada mandam celebrar na igreja do N. S. Passos às $7 \frac{1}{2}$ horas da manhã de sábado, 24 do corrente, pelo que antecipam seus agradecimentos. ${ }^{30}$

Anúncios como estes eram verdadeiros atestados da competência e das habilidades dos profissionais da cura ali envolvidos e citados elogiosamente pelos parentes da paciente, mesmo que esta tenha falecido. Os esforços e desvelos dos médicos e da parteira devem ter atenuado o sofrimento daquela mulher atacada de cruel enfermidade.

Anos depois, outra notícia publicada nos jornais da capital traz novamente Joana Mehnert aos holofotes, mostrando como o ofício de parteira tratava com questões da intimidade feminina e, portanto, atraía a vigilância dos órgãos públicos, tornando suspeitas as suas profissionais. Outrossim, mostra como atuar nesse campo tornava essas mulheres, muitas vezes, cúmplices de atos corriqueiros, mas que podiam ser facilmente imputados como desonestos e imorais. Afinal, estava em jogo ali a autonomia daquelas mulheres com relação ao gerenciamento de seus próprios corpos e de suas sexualidades. Em 16 de junho de 1909, um a pedido foi publicado na Seção Livre do jornal $A$ Federação:

Declaração - A abaixo-assinada declara que não tem fundamento algum a notícia dada pela Gazeta do Comércio e referente ao caso de um menor exposto na escadaria da Santa Casa. A verdade é esta: Tendo alugado um quarto independente no prédio $n^{\circ} 52$, da rua Dr. Flores, onde também reside a parteira Joana Mehnert, ali deu à luz uma criança na madrugada de 8 do corrente. Como não pudesse criar o meu filho, resolvi, espontaneamente, mandar colocá-lo na roda dos expostos. Assim fiz, mandando o preto Edmundo de tal (vulgo Cinco Paus), a quem dei $10 \$ 000$, sem que disso tivesse conhecimento a parteira Joana Mehnert. Porto Alegre, 15 de junho de 1909. Rosa Klaus (a firma está reconhecida pelo notário Arthur Graciliano da Silva). ${ }^{31}$

Não conseguimos localizar o número referido acima da Gazeta do Comércio, mas parece que este periódico tentara incriminar a parteira Joana, provavelmente insinuando ter partido dela a ideia de abandonar a criança recém-nascida na roda dos expostos. A declaração acima tenta inocentar Joana, não Ihe atribuindo qualquer papel no cuidado da parturiente e no parto de Rosa Klaus e mesmo afirmando que

30 HDBNRJ - Jornal A Federação, folha 3, anúncios, 21 fev. 1900.

31 HDBNRJ - Jornal A Federação, 16 jun. 1909. 
esta mulher grávida não havia se hospedado na casa daquela parteira, mas apenas um quarto independente no mesmo prédio da rua Dr. Flores. Três dias depois foi a vez da própria Joana se pronunciar através de um outro a pedido:

\begin{abstract}
Seção livre - Ao Público - Voltando a tratar do caso do aparecimento de uma criança na escadaria da Santa Casa, com o qual eu nada tenho, a Gazeta do Comércio disse, ontem, haver afirmado Augusto Sager que eu insistira com Rosa Klaus, para que esta assinasse a declaração que apareceu na imprensa. É absolutamente falso. Nada pedi a Rosa Klaus. A declaração foi espontaneamente feita. O que é verdade é que o mesmo Augusto Sager se opunha a que Rosa firmasse aquele documento, dizendo que, se o fizesse, ficaria sujeita a processo. E disso há testemunha. Pode a Gazeta continuar a desenrolar o fantasmagórico romance. Eu é que não mais voltarei à imprensa, porque não tenho tipos de graça a minha disposição. O público sensato que me julgue. Porto Alegre, 19 de junho de 1909. Joanna Mehnert. ${ }^{32}$
\end{abstract}

Se o público se convenceu da inocência de dona Joana nós não sabemos, mas o $2^{\circ}$ promotor público, o dr. João Neves da Fontoura, apresentou denúncia contra ela e Edmundo Antônio da Silva, o preto Cinco Paus, que foi pago por Rosa Klaus para levar o seu filho recém-nascido até a roda dos expostos da Santa Casa de Misericórdia de Porto Alegre. ${ }^{33}$ Mas o caso não foi longe, em dezembro do mesmo ano de 1909, o juiz de comarca da $2^{\mathrm{a}}$ vara dr. Escobar Júnior julgou improcedente a denúncia contra Joana e Edmundo, por não se terem dado os elementos característicos do crime de abandono de criança recém-nascida. ${ }^{34}$

\title{
Considerações finais
}

RELENDO A "PIADA" que colocamos em epígrafe deste artigo, notamos que o diálogo que ali se trava é entre um empregado (criado) e o seu patrão. Assim, talvez a anedota possa ser lida sob um viés classista, com o trabalhador jogando com a ironia ao relatar a morte da patroa como uma cousa melhor. Se nos deixarmos influenciar por Robert Darnton, ${ }^{35}$ podemos ver nessa piada um ataque simbólico ao patrão e a sua mulher.

Muitas das mulheres tratadas neste artigo eram jovens trabalhadoras do serviço doméstico, que gerenciaram suas vidas afetivas e sexuais sob o controle dos patrões, sofrendo destes, muitas vezes, abusos que elas tiveram que administrar psicológica e fisicamente. Essas trabalhadoras, quando engravidavam, recorriam a redes de solidariedade feminina formadas por suas colegas de trabalho, de vizinhança e pelas parteiras. Mesmo que as parteiras, como profissionais que muitas delas eram, exigissem retribuições pecuniárias, podemos ver que elas negociavam com a clientela feminina, principalmente a de mulheres populares (criadas, costureiras etc.), abatendo e parcelando os valores cobrados, dando pequenas consultas e fornecendo receitas de graça.

32 HDBNRJ - Jornal A Federação, 10 jun. 1909.

33 HDBNRL - Jornal A Federação, folha 4, seção judiciária, movimento forense, 11 set. 1909.

34 HDBNRL - Jornal A Federação, folha 4, seção judiciária, movimento forense, 4 dez. 1909.

35 DARNTON, Robert. O grande massacre de gatos. Rio de Janeiro: Graal, 1986. 
A "piada" em epígrafe, assim, pode ser lida como um deboche à mortalidade dos patrões, que também padeciam das mesmas fragilidades de seus subordinados. E uma crítica social, já que o sofrimento e a morte de muitas trabalhadoras do serviço doméstico derivavam de abusos sofridos dos patrões.

Por outro lado, a "sátira" do jornal começa com a dispensa da parteira e com ela de toda a rede que podia estar junto da parturiente. A misoginia é evidente e mostra o papel dos jornais e de suas piadas em constituir uma sociedade hostil ao feminino, suas produções, suas demandas, suas vidas e suas mortes. Até hoje.

\section{Abreviaturas:}

AHCMPA - Arquivo Histórico Cúria Metropolitana de Porto Alegre APERS - Arquivo Público do Estado do Rio Grande do Sul HDBNRJ - Hemeroteca Digital da Biblioteca Nacional PRR - Partido Republicano Rio-grandense 